\title{
AZ IPAR 4.0 ÉS A DIGITALIZÁCIÓ KOCKÁZATAI
}

\section{INDUSTRY 4.0 AND THE RISKS OF DIGITIZATION}

\author{
Fregan Beatrix ${ }^{1}$, Kocsis István ${ }^{2}$, Rajnai Zoltán ${ }^{3}$ \\ ${ }^{1}$ Nemzeti Közszolgálati Egyetem, fregan.beatrix@uni-nke.hu \\ ${ }^{2,3}$ Óbudai Egyetem, Biztonságtudományi Doktori Iskola, Budapest, \\ ${ }^{2}$ kocsis.instvan@phd.uni-obuda.hu \\ 3rajnai.zoltan@bgk.uni-obuda.hu
}

\begin{abstract}
Itt Industry 4.0 is considered as the digital transformation of manufacturing. Changes due to digitalization are running at a continuously accelerating speed, developments change our whole world, including production and labor market completely. An overview of labor market effect of overall digitalization is provided. Predictions, and forecasts for labor market phenomena due to robotization is given in terms of overall changes of employment. Changes in employment structure are influenced by several factors of computerizability of the individual work activities of various jobs.
\end{abstract}

Keywords: Industry 4.0, digitalization, automation, robotization, artificial intelligence, human resources, labor market, education.

\section{Összefoglalás}

A digitalizáció átalakítja a világot. Az Ipar 4.0, a gyártás digitalis átalakulása átalakítja a munkaerőpiacot. A negyedik ipari forradalom gyors műszaki fejlődése hatalmas kihívások elé állítja a társadalmat és a politikai vezetőket.

Azzal kell-e szembenéznünk, hogy az intelligens automatizáció, a robotizáció, vagy hoszszabb távon a mesterséges intelligencia csökkenti a foglalkoztatást, és végül versenyképtelenné teszi az emberi munkaerőt a gépekkel szemben?

Kulcsszavak: Ipar 4.0, digitalizáció, automatizálás, mesterséges intelligencia, emberi eröforrás, munkaerőpia, oktatás.

\section{Bevezetés}

Az Ipar 4.0 típusú megoldások a fejlett gazdaságokban a munkahelyek egyre nagyobb részét érintik. A jövő gyártási módszerei, folyamatai és a digitális gazdaság az emberi erőforrások iránti szükségletet gyökeresen átalakítják. Jelentősen csökken, vagy éppen megszünik a kereslet számos munkakör iránt. Feltételezhető azonban, hogy ezzel egyidejüleg az új müszaki környezet, az új üzleti modellek és az új társadalmi kihívások nem csak a jelenlegi munkahelyeket és munkaköröket alakítják át, hanem új munkahelyeket is teremtenek. Ezen folyamat során új típusú, korábban 
nem létező munkakörök és szerepek létrejötte is várható.

A digitalizáció által húzott gyorsan és állandóan változó világ feltételei között lehetetlen ezen folyamatok hosszú távú egyensúlyát megjósolni. Ezért ebben a környezetben a hosszú távú előrejelzéseken alapuló döntéshozatal ezért nem oldhatja meg sem a munkaerőpiac kérdéseit, sem a társadalmi kihívásokat. A társadalom jellemzően sokkal lassabban alkalmazkodik a változásokhoz. Ennek következtében egy legalább egyensúly közeli állandósult dinamikus egyensúlyi állapot fennmaradása is kérdéses lehet, illetve ennek fenntartása a komoly zavarok, vagy éppen az összeomlás elkerülésére is komoly kihívást jelent.

A termelésnek a fejlett országokból a fejlődő országok való kihelyezése az európai munkahelyek számának csökkenéséhez vezetett. Nyugat-Európában a 15\%-osra becsült GDP-arányos ipari termelés szintjén mintegy 5 millió ipari munkahely szünt meg az elmúlt 15 év során [1].

\section{A digitalizáció hatásai}

A digitalizáció eredményeképpen az információ globálisan nagy mennyiségben, nagyon kis késleltetéssel rendelkezésre áll. A globális jelenségek sokkal erősebben hatnak a piaci versenyre, mint bármikor korábban.

A munkaerőpiaci polarizáció erősödését jelzi, hogy a foglalkoztatás az alacsony, illetve a magas bérkategóriájú munkakörökben növekszik, és a közepes bérek szegmensében csökken [2]. A nehezen helyettesíthető munkatársak magas béreket tudnak kiharcolni. Az alacsony bérezésű munkákat gyakorlatilag bárki elvégezheti.

\section{Előrejelzések}

A történelmi tapasztalat azt mutatja, hogy a társadalom a termelöerők jelentős átrendeződését, az ipari forradalmakat csak hosszabb idő alatt tudja követni. Ez a kö- rülmény gazdasági és társadalmi válságokhoz, esetleg összeomláshoz vezetett.

Az Európai Bizottság tanulmánya [3] szerint a digitalizáció munkaerőpiaci hatásai a következő tényezők alapján vizsgálhatók: a munkaerőpiac dinamikája; munkakörülmények változása; a szükséges ismeretek; az EU és a tagállamok politikái. Új munkahelyek létrejöttét többek között a következő tényezők eredményezhetik: új termékek, termelőeszközök és szolgáltatások kifejlesztése; a versenyképesség javulása.

Az Ipar 4.0 a versenyképességnek olyan új modelljét hozhatja, melynek mozgatórugói az automatizáció és a robotizáció, vagyis belföldön is elkerülhetővé válhatnak a magas bérköltségek. Az új müszaki megoldásokba, új termékekbe és szolgáltatásokba való befektetés eredményezheti a pozitív hatásokat, melyek mintegy 10 millió új munkahelyet hozhatnak létre Németországban. Vagyis a felállított modell előrejelzése szerint az Ipar 4.0 megoldások növekvő bevezetése mellett kismértékü pozitív mérleget lehet felállítani. [4]

A BCG modellszámításai szerint, amennyiben az Ipar 4.0-nak köszönhetően mintegy 0,5 és 1,5 százalék közötti bevételnövekedési forgatókönyvekkel számolnak, az ipari foglalkoztatás változása az 1,8 milliós csökkenés és a 6 milliós növekedés között prognosztizálható Németországban a 2015 és 2025 közötti időszakban.

\section{Válaszok a vállalati emberi erő- forrás-gazdálkodásban}

A gyors és újszerű munkaerőpiaci változásokra a vállalatoknak az emberi erőforrásaikkal kapcsolatos intézkedéseik során reagálniuk kell. A vállalatok számára javasolt munkaerőpiaci stratégia és intézkedési terv legfontosabb elemei az alábbiak:

- Az emberi erőforrások stratégiai tervezése.

- Az Ipar 4.0-ra irányuló munkaerő toborzása.

- Felkészülés a tehetség iránti versenyre. 
- A munkatársak megtartása és átképzése.

- Új szervezeti és munkavégzési modellek kialakítása.

\subsection{Oktatás és képzés}

A munkaerőpiaci követelmények és az elérhető munkaerő között tudásban, képzettségben jelentős szakadék van. A becslések alapján informatikai szakemberekből különösen nagy hiány tapasztalható: EU szinten 850 000, Németországban 120 000, Magyarországon mintegy 22000 informatikus hiányzik a munkaerőpiacról.

A digitalizáció következtében várható változásokra válaszul az oktatási rendszert az alábbi intézkedésekkel javasolják átalakítani. [5]

- A matematikai, természettudományos, mérnöki és informatikai (MTMI, amerikai használatú betüszóval STEM) szakokon való oktatás erősítését, mindenek előtt a hallgatói létszámok növelését ezeken a szakokon.

- Rugalmasabb, szélesebb körü tudás és készségek kialakítása az oktatási rendszerben, hogy a végzett szakemberek jobban alkalmazkodhassanak a változó és sok esetben összetett munkahelyi szerepekhez.

- Új képzések indítása, a meglévő tananyagok rendszeres frissítése, beleértve az interdiszciplináris szakokat is.

- Új képzési formák bevezetése, beleértve az élethosszig való tanulási modellt; nyílt és on-line képzéseket; az oktatási és a vállalati szféra együttmüködésével folyó oktatást;

\subsection{Most és 2030 után}

A jelenlegi elképzelések, stratégiák, tervek, becslések és jóslatok időtávlatai általában 2025-ig, 2030-ig terjednek. Milyen megfontolásokat vethetünk fel az ezt követő időkre?

Hagyományosan az ember és ember közötti verseny az olcsó munkaerő iránti igényből indult ki, mely a munkaerö regionális és globális területi átrendeződéséhez vezet. A folyamat természetesen területi egyenlőtlenségeket hoz létre.

A magas képzettségü, a legújabb technológiákat ismerő, azokban gyakorlott munkatársak iránti igény átrendezi a jövedelmek eloszlását. A társadalmi rétegek és csoportok közötti jövedelemegyenlötlenségek feszültségeket gerjesztenek, társadalmi és politikai problémákat okoznak.

A gépeknek az emberrel folytatott versenye azzal kezdődött, hogy erősebbekké és gyorsabbakká váltak az embernél. Pontosak, sosem betegek, nincsenek személyes igényeik. Ahogyan az a történelemböl ismert, az embernek gépekkel való helyettesítése a fizikai munkában számos estben társadalmi problémákhoz vezetett. De továbbra is megörizte az ember az intelligens munkát, mint saját, kizárólagos területét.

Ha azonban a gépek intelligensebbekké válnak az embernél, a szellemi munka végzése is jelentős mértékben áttevődhet az emberről az intelligens gépekre, az emberi munka végső esetben feleslegessé válhat. A mesterséges intelligencia fejlesztése nagy lehetőség és komoly fenyegetés egyben:

"A mesterséges intelligencia lesz az utolsó találmányunk?” (J. Barratt)

"Nagyon oda kell figyelnünk a mesterséges intelligenciára, mert az több veszélyt rejthet, mint az atomfegyverek" (Elon Musk, Tesla Motors)

A szingularitás az időpont, amikor a mesterséges intelligencia meghaladja az emberi intelligenciát. Az eddigi becslések ezt az időpontot 2040 és 2100 közé helyezték.

Egy, az Oxford Martin Program keretében az Egyesült Államokban végzett felmérés [6] azt kutatta, hogy egyes szakmák munkahelyeit mennyire veszélyezteti a számítógépesítés (és automatizálás). 702 szakma számítógépesíthetőségének valószínüségi listáját állították össze, és azonosították a számítógépesítés által leginkább 
fenyegetett foglalkozásokat. A felmérés összefoglaló eredménye szerint a következő 10-20 évben az Egyesült Államok munkahelyeinek 47 százaléka kerülhet veszélybe. A gépek általi helyettesíthetőség ellen a felmérés szerint az adott foglalkozást az védheti legjobban, ha annak végzése során finom érzékelés és mozgás; kreatív intelligencia (eredetiség, müvészet); társadalmi intelligencia (érzékenység, tárgyalási gyakorlat, együttmüködési készség) szükséges.

$\mathrm{Az}$ eredményt csak a tudomány és a technológia jelenlegi színvonalán lehet értelmezni. A helyes kérdésfeltevés valószínüleg nem az, hogy az ember helyettesíthetö-e egy adott munkaterületen. Valószínüleg csak idő kérdése.

Láttuk, hogy az előrejelzések új típusú munkahelyek létrejöttét is jósolták. A gyakorlati kérdés az, hogy a létrejövő munkahelyek száma kiegyenlíti-e a megszünő munkahelyekét, fenntartható-e ez az egyensúly folyamatosan, illetve fenntartható-e ez a munkahelyteremtö folyamat a robotok folyamatosan javuló versenyképessége mellett is.

\section{5. Összegzés}

Az Ipar 4.0 és a digitalizáció új típusú foglalkozásokat teremt és a jelenlegi munkaköröket is megváltoztatja. Az automatizáció előretörése és a termelékenység javulása munkahelyek megszünését, illetve más régiókba való áthelyeződését is eredményezi. Megbízható előrejelzést készíteni a gyorsan változó, és a változások szabályszerüségeit is változtató környezetben lehetetlennek tünik, de modellek kidolgozása segíthet a folyamatok mélyebb megértésében.

A digitalizáció a müszaki fejlődéssel párhuzamosan az egyes ágazatokban és az egyes szakmákban eltérő sebességgel zajlik.

A munkaerőpiacon az előrejelzések alapján várható, hogy a legmagasabb kép- zettséget, illetve egyes speciális készségeket igénylő foglalkozásokban az emberi munkaerő intelligens gépekkel történő helyettesítése jelenleg a legkevésbé valószínü, illetve ezeken a területeken várható a foglalkoztatás növekedése is. A közepes bérkategóriákban legnagyobb az emberi munka helyettesítésének valószínűsége, illetve a foglalkoztatás ezeken a területeken csökken, vagy stagnál.

A digitalizáció, és hosszabb távon kifejezetten a mesterséges intelligencia nagy lehetőségeket, kihívásokat és kockázatokat rejt. A digitális átalakulással jellemezhető versenynek lehetnek nyertesei és vesztesei minden szinten: az egyének, a vállalatok, a foglalkozások, az ágazatok, az országok, a kormányok, a társadalom szintjén. A kihívások és a kockázatok kezelése minden érdekelt közös felelössége.

\section{Szakirodalmi hivatkozások}

[1] Roland Berger consultants: The Industry 4.0 transition quantified Think Act. Beyond the mainstream. (Roland Berger GmbH., München, Németország. 2016)

[2] Autor, D.H.: Polanyi's Paradox and the Shape of Employment Growth (NBER Working Paper 20485. National Bureau of Economic Research. US. 2014)

[3] Employment and skills aspects of the Digital Single Market strategy. ISBN 978-92-8238377-3 (Európai Bizottság, DG for Internal Policies. 2015)

[4] The Boston Consulting Group: Man and Machine in Industry 4.0 - How will technology transform the industrial workforce through 2025? (Boston Consulting Group. 2015)

[5] The future of work: Digitalisation in the US labour market ISBN 978-92-823-9002-3 (Európai Bizottság, DG for Internal Policies. 2016)

[6]Frey, C.B., Osborn, M.A.: The Future of Employment: How susceptible are jobs to computerisation? (Oxford Martin Programme, Oxford University. 2013) 